\author{
K.T. Tleuzhanova ${ }^{1}$, Z.S. Kupeeva ${ }^{1}$, A.Z. Igembekova*, G.M. Magauina ${ }^{2}$ \\ ${ }^{1}$ Karagandy University of the name of academician E.A. Buketov, Karaganda, Republic of Kazakhstan; \\ ${ }^{2}$ Karaganda Technical University, Republic of Kazakhstan \\ (Corresponding author's E-mail: 84kenje@mail.ru)
}

\title{
Prospects and problems in the field of modern education in Kazakhstan
}

\begin{abstract}
This article discusses an important for education topic of the application of programs and standards of effective education in the Republic of Kazakhstan. It also analyzes the current state of the education sector and the main policy documents in the education sector that regulate its effectiveness. The article reveals the problems of Kazakh higher education, such as the oversaturation of the market with educational institutions (universities), the expensive cost of education, and the lack of technical specialists. The State Program for the Development of Education of the Republic of Kazakhstan for 2019-2025 adopted in 2019 is substantiated as the idea of one of the possible ways to eliminate defects and gaps in education. Summarizing practical experience, the article examines the key stages of changing the state of the education system and its modernization. The improvement of entrance exams to leading universities of our country as a part of increasing the competence of specialists is being considered. In order to saturate production and enterprises of labor-deficient regions with personnel the implementation of the social project "Mangilik El Zhastary Industryaga" continues. This implies providing jobs for university graduates, including in rural areas, taking into account the needs of the labor market. In conclusion, all possible ways of improving the education system are examined, which are reflected as the planned changes in the State program and should have a beneficial effect on the system of higher and postgraduate education in the republic and increase its prestige in the eyes of potential applicants.
\end{abstract}

Keywords: education market, results of testing, graduates of general education, schools, labor markets, over the past three decades, educational services, paid basis, increased requirements, modern trends, education system, qualitative reform, world standards.

\section{Introduction}

Higher education is the most important social institution functioning to meet social needs and therefore responsive to internal and external changes and processes. Constantly increasing in volume and more and more versatile in content, intercountry economic ties create the need for a universal cadre of specialists receiving professional training in national universities. This leads to the fact that the content of national systems of higher education naturally tends to the so-called "world standards" developed by world science and technology. The processes of globalization also requires a new target orientation from the national higher education systems, taking into account the needs for international solidarity. Under the conditions of globalization the universalization of the content and technologies of education is inevitable, which cannot be stopped with the existing world information and communication systems in the form of the Internet [1].

Internationalization of higher education is taking place and gradually acquiring the features of a qualitatively new stage such as integration, the all-round convergence of national educational systems, their complementarity. The transformation of higher education into a global social system is characterized by many interrelated elements of different levels and character. Occupying their specific place in the educational services market, universities interact in the form of cooperation or rivalry, developing the main guidelines for this market. The need for the stability of the higher education system presupposes its constant development and adaptation to the changing conditions of the modern world. Thus, the integration of higher education into the world system is an objectively developing process in which one can try not to be included, but which cannot be overlooked.

\section{Discussion and Results}

International cooperation, being a powerful lever for the development of the world higher education system, is designed to solve a number of urgent tasks, such as compliance with the adequacy of the content and level of higher education to the needs of the economy, politics, socio-cultural sphere of society, leveling the training levels of specialists in different countries and regions, strengthening international solidarity and partnership in higher education, sharing knowledge and skills in different countries and on different 
continents, promoting the development of higher education institutions, especially in developing countries, including through funding from international funds, coordinating the activities of educational institutions for the development of higher education, stimulating an overall increase in the flexibility, coverage and quality of higher education, which helps to eliminate the causes of brain drain, encouraging competition between scientific schools and educational systems, combined with academic solidarity and mutual assistance.

For several decades the European Union has been developing and implementing a holistic policy in the field of higher education, forming supranational institutions of coordination and management. These processes naturally led EU politicians to create the idea of the Bologna Declaration and initiate the Bologna Process. The essence of the declaration accurately reflects the specific tasks of transformations formulated in it for the countries participating in the process for the coming years. A single educational space should allow the national education systems of European countries to take the best that partners have by increasing the mobility of students, teachers, management personnel, strengthening ties and cooperation between European universities, etc. As a result, a united Europe will become more attractive in the global educational market. To ensure harmonization, national systems of higher education should become transparent, as comparable as possible, which can be achieved through the wide distribution of the same type of educational cycles (bachelor's degree), the introduction of uniform or easily recalculable systems of educational loans (credit units), the same forms fixing the qualifications obtained, mutual recognition of academic qualifications, developed structures for ensuring the quality of training of specialists, etc. [2].

Over the past two decades Kazakhstan has stepped up international cooperation in the field of higher education. Integration of the country's higher education system into the world educational space is one of the long-term strategic priorities of the republic. A significant number of bilateral intergovernmental agreements on cooperation with higher schools of foreign countries have been signed, the number of direct agreements with foreign universities has significantly increased.

The current state of the education system testifies to the incomplete coverage of organized preschool education and training programs for children aged one to five years. The content of education in a modern general education school remains factual, state standards based on a subject approach are outdated. There is no competence-based approach focused on the individuality of the student. Education at school does not give the student a clearly expressed positive motivation for choosing a life path, interests and prospects. Only $30 \%$ of high school students consciously choose a professional activity that matches their abilities. Consequently, $70 \%$ of high school students have low self-esteem and are not prepared for independence in life [3].

In addition, UNESCO studies and the results of testing graduates of general education schools over the past five years indicate a steady decline in the quality of education. In the conditions of insufficient profiling at the upper stage of secondary education, school graduates remain unclaimed in the labor market. Primary and secondary vocational education does not fully satisfy the needs of the individual and society and cannot solve the problem of personnel training due to the new requirements for the level of qualifications of technical workers and mid-level specialists of technical, service and managerial labor. The content of educational programs for primary and secondary vocational education by qualification levels does not comply with the principles specified in the Recommendations on Technical and Vocational Education (UNESCO, 1974) and the criteria for the programs of the International Standard Classification of Education (ISCED, 1997).

Certain negative tendencies also began to grow in the higher education system. Reducing the requirements for admission to a university in the absence of the intellectual, personnel, material and technical potential of individual universities and their numerous branches corresponding to modern requirements has led to an excessive increase in the number of specialists, which has led to oversaturation of the labor market with unclaimed personnel. This was facilitated by mass training in narrow-profile specialties, focused only on stable industries and consumers [4].

The lack of a mechanism for mutual accounting of our educational programs and foreign analogues, mutual recognition of educational documents hinders the academic mobility of students, teachers and specialists of service and managerial labor.

The improvement of the country's economic situation at the beginning of the new century had a generally positive effect on the education system: the construction of new schools resumed, funds began to be allocated to strengthen the material and technical base of educational organizations.

However, this is not enough to radically change the state of the education system. There is a clear backlog of the educational system from the needs of a market economy and an open civil society. The main 
reasons for this situation in the education system are the predominance of subjectivity in the final assessment of the quality of education, which gave rise to certain negative consequences at all its levels; insufficient sensitivity of the education system to innovations and the lack of proper motivation to introduce a quality learning system; insufficient efficiency of the mechanisms for the formation of ethnocultural and civic identity in the younger generation based on knowledge of the history of the state, the state language and national cultural values of the peoples of Kazakhstan; inconsistency of the material and technical base, educational and laboratory equipment, educational and methodological literature lack of motivation to ensure the high quality of education in the training system the outflow of personnel a decrease in material incentives for pedagogical work.

The current situation in the field of education indicates the need for consistency in overcoming negative phenomena, cardinal organizational, structural transformations, updating the content of education and improving the quality of training in accordance with the modern socio-economic and political conditions of the republic's development and the progressive experience of highly developed countries. Measures are being taken to modernize the higher education system, the main attribute of which is joining the Bologna process.

It is known that direct measurement of the quality of higher education is difficult. Analysts use various methods to determine the quality of education, but none of them gives a complete picture. One of the methods of testing students and graduates of universities is carried out irregularly, it uses various methods, which complicates the comparability of results, and there are doubts about the impartiality and reliability of such procedures [5].

More objective indicators are the resource provision of the university (the level of funding, the number of teachers per student, including those with advanced degrees, library funds, the availability of computers, Internet access, etc.), but they give an idea of the possibilities of high-quality learning not allowing to judge to what extent these opportunities are realized.

Evaluation of the quality of higher professional education can also be carried out through the system of ratings of higher education institutions. The systematic compilation of ratings of educational institutions of different levels according to certain criteria will create a competitive environment in the higher education system. Educational institutions create an internal quality management system and constantly improve it in order to meet the needs of society, individuals and the labor market. However, in this case it is necessary to clearly work out the technology for compiling ratings, since it is necessary to prevent an unfair assessment of the activities of educational institutions.

The quality of higher education can also be judged with certain reservations by the market assessment of a university diploma. Employers, being interested in capable and knowledgeable employees, should value a diploma from a university known for the high level of its programs, the quality of teaching and a demanding attitude towards student knowledge and curriculum implementation. Such a diploma is, firstly, evidence of the professional competence of its holder, and secondly, it reliably confirms the ability of the holder of the diploma, who has managed to successfully cope with a complex academic program. Holders of such diplomas can count on getting a good, well-paid job, which makes the university itself prestigious and attractive for students, ensuring its professional and financial well-being. Thus, market incentives to improve the quality of higher education emerge in the labor market.

Education is the main priority and the main indicator of development in all civilized countries of the world. Indeed, countries compete not only in goods and services, they compete with systems of social values and the education system. The task of joining the Republic of Kazakhstan among the 50 most competitive countries in the world can be solved if the country has highly qualified specialists with knowledge of science-intensive technologies, managerial skills, who are able to, navigate the market economy, and an effective education system is created that meets the needs world market economy.

One of the main problems of higher education is its inaccessibility, or rather high cost. According to statistics, out of 16 million of the population of Kazakhstan, only $15 \%$ are in the age group involved in the educational process. In fact, the real number of people wishing to get higher education in the country is much higher. For example, in rural areas and auls there are many talented young people who, due to financial problems, are unable to get higher education.

Continuity of knowledge and free access to education is a condition for the development of any civilization. When the state deliberately turns education into a sphere of gaining profit, this not only adversely affects the quality of education, but inevitably leads to the degradation of the state. One of the most important directions in the development of education is international cooperation, the main task of which is the integration of the education system of Kazakhstan into the world educational space. 
International cooperation in the field of education is regulated by the legislation of the Republic of Kazakhstan and is carried out on the basis of international treaties, agreements and conventions. Taking the world education standard as a basis for reforming, it is necessary to use the experience of industrially developed countries that have long recognized the role of education in the development of the state.

There are many problematic situations in the field of higher education, in the resolution of which the experience of foreign countries can be safely applied in practice in our country. Among them is the ubiquitous problem of underfunding. Having solved it, it is possible in one fell swoop to resolve several problems that are very important for the development of higher education. This is the so-called brain drain caused by low wages, and not so much abroad as to various commercial structures. Personnel hunger concerns not only the teaching staff, but also potential teachers, scientists from among students, who prefer to earn money rather than develop national science. In comparison, in South Korea the salary of a young teacher is the equivalent of 2000-2500 US dollars, which is one and a half times higher than the average in our country. The lack of funding also affects the material and technical equipment of higher educational institutions and, most importantly, the introduction of information technologies in the field of education. As you know, modernization currently is more concerned with informatization. And the introduction of such innovations as distance learning is generally inconceivable without the introduction of information technology [8].

Kazakhstan inherited mainly the principles and methods of Soviet education and pedagogy. As for the natural, exact and technical sciences, a relatively high level of the quantitative and qualitative state of education remains here. The changes here are insignificant, with the exception of the lack of demand for specialists in these sciences, which leads to a brain drain from the republic.

In the system of higher professional education the gap in the interaction of universities with the science sector, production and experimental bases is increasing, which leads to a decrease in the quality of the educational process and the practical training of future specialists. The methodology for determining the rating of universities in Kazakhstan also raises many questions. It is mainly based on quantitative indicators. In the methodology for determining the rating of universities, such a concept as the basic category of the quality of the taught programs and the knowledge of students is not considered.

\section{Conclusion}

The content of the rating has not been interpreted clearly. The methodology for determining the ranking of universities uses a limited set of indicators and the number of data collection methods.

Thus, as we see, there are still a large number of shortcomings and gaps in the republic's higher education sector. One of the possible ways to eliminate them is the State Program for the Development of Education of the Republic of Kazakhstan for 2016-2019, adopted in 2019.

The main goal of this program is to provide sectors of economy with competitive personnel with higher and postgraduate education, the integration of education, science and innovation.

To achieve this goal the program provides for the sequential passage of certain stages, which we will describe below. The formation of the state educational order for the training of personnel with higher and postgraduate education will be carried out in accordance with the needs of the labor market. Since 2019 the volume of state educational orders is determined by industry associations of employers based on the needs of state and industry programs, including industrialization maps, distribution of productive forces, regional development programs until 2020, regional specialization schemes for the optimal use of agricultural land for the production of specific types of agricultural products. This will ensure the demand for university graduates, therefore all sectors of the economy will be provided with qualified personnel.

In our opinion, this goal is very important and promising, but to achieve it some time is needed to adapt the goal and restructure the system of employment of graduates. Achieving this goal, in addition to increasing the importance and prestige of the education system, will also solve some of the social problems: a partial solution to the problem of employment of university graduates, a partial solution to the problem of unemployment, and as a result, an improvement in the social situation in the republic.

As part of the modernization of pedagogical education a mechanism will be developed for introducing new criteria for admission to pedagogical specialties, in particular, when entering universities for pedagogical specialties, it is planned to introduce a special exam to determine the propensities of applicants for pedagogical activity. In order to develop the professional skills of future teachers the issue of introducing a pedagogical internship will be worked out in 2019. 
As part of improving the rules for admission to universities in 2019 the issues of including SAT, ACT tests in an alternative list of admission procedures to a university on a par with the UNT, participation in subject Olympiads have found a detailed study. The mechanism of admission and training of personnel in bachelor's, master's and doctoral studies will be improved with market regulation of the volume of state educational orders in universities, regardless of the form of ownership.

Since 2019 the issue of switching to credit and per capita financing of higher education with the development of proposals for financing the state educational order, taking into account the volume of academic loans being mastered, with the involvement of employers, has been discussed.

Admission to magistracy and doctoral studies is planned to be carried out if there is at least 1 year of practical work experience for magistracy, at least 3 years for doctoral studies, based on IELTS, TOEFL, DELF, DALF, TestDaF, DSD II certificates (since 2018), with the provision of the right of choice for applicants of a higher education institution (from 2019), as well as the requirements for the level of the scientific component of postgraduate education programs (from 2019). Since 2019 training for doctoral studies has been carried out in partnership between the state and employers.

In order to saturate production and enterprises of labor-deficient regions with personnel the implementation of the social project "Mangilik El Zhastary Industry" will continue. Every year a state educational order will be provided for universities in labor-deficient regions for training personnel from among young people in labor-surplus regions with their subsequent employment at the place of study. For the employment of university graduates who studied under the state educational order, a roadmap will be developed annually together with the ministries of health and social development, culture and sports, agriculture and local executive bodies. This implies coordinating the actions of interested state and local executive bodies in providing employment places for university graduates, including in rural areas, taking into account the needs of the labor market [8].

Also, the study of the issue of working out graduates of Nazarbayev University on the territory of the Republic of Kazakhstan deserves close attention. Important elements of this task will include the model of the competitiveness of national universities developed in 2016, the improvement of the rules of admission to universities for foreign citizens on a paid basis (since 2017), the further development of academic mobility, including through the arrival of foreign students, as well as the development and implementation of educational programs in English (2019-2023), holding permanent forums of higher education together with foreign countries and partner universities.

The work to create a level playing field and barrier-free access for students with special educational needs (ramps, lifts, elevators, as well as providing information and library resources, and others) will continue.

This also provides for the further expansion of distance education technologies, the opening of massive online courses, the development of special educational programs and teaching materials, as well as the retraining of the teaching staff of universities to work with students with special educational needs. By 2020 the share of universities that have created equal conditions and barrier-free access for students in this category will be $100 \%$. In 2017-2018 it is planned to create a Unified Information System of Education and Science by attracting investments from extra-budgetary sources, including using PPP mechanisms.

Management in education, including the institutional level, will receive further improvement. This includes taking measures to increase the number of universities with corporate management principles (supervisory or board of trustees, boards of directors), attracting foreign specialists to the top management of universities, passing by the management staff of all civil universities, regardless of the form of ownership of advanced training courses in modern management in higher education, including through extrabudgetary funds. The principle of openness and accountability to society is planned for implementation, which will be implemented through the annual reporting of rectors to the public. Rectors' performance will be evaluated through key performance indicators (KPI).

Measures are also being developed to increase the responsibility of universities, including social responsibility, to society for the quality of education. It is planned to develop a methodology for assessing the effectiveness of costs, the effectiveness of universities in the conditions of independence. The phased implementation of the experience of Nazarbayev University in matters of academic and managerial independence in civil universities will continue. Universities implementing the experience of Nazarbayev University have developed a corresponding roadmap since 2016. The administration and teachers of universities will be trained to work in conditions of academic and managerial independence through appropriate refresher courses, including through extra-budgetary funds. 
The principles of corporate governance are planned for implementation through the gradual expansion of the academic, managerial and financial independence of universities, and a mechanism for the formation of the endowment fund of universities will also be developed. Issues of the gradual granting of academic freedom to universities, primarily those that have passed international accreditation, will be worked out. Gradual implementation will result in the transformation of universities into non-profit organizations, providing for the creation of corporate governance bodies. Questions of the creation of non-profit joint stock companies with $100 \%$ state participation on the basis of state and national universities will also receive detailed study. It is planned to develop proposals for the transformation of private universities into other organizational and legal forms.

The transition to a new organizational and legal form will provide for the creation of supervisory boards, endowment funds, annual public reporting and audit of financial activities. After changing the organizational and legal form of universities, the issues of granting financial independence with the introduction of a single transparent accounting department will receive a detailed study. All stakeholders already carried out an information campaign on the transition to a new organizational and legal form in 2016.

In 2017 we began to provide grants to preparatory departments of universities in order to improve the language knowledge of graduates. In the 2017-2020 academic years, there are 500 master's grants and 900 bachelor's grants for teaching in English. The Bolashak program is planned to be expanded by issuing 500 grants for teachers and teaching staff of universities. Additional measures will be taken to improve the qualifications of teaching staff at language courses, distance learning in English, adaptation of foreign textbooks and teaching materials in English for universities, etc. [8].

From 2017-2018 basic universities that train personnel for SPIID enterprises in 6 specialties will switch to English-language training with the development of educational programs, textbooks and teaching materials in English for universities. By 2021 bachelor's degree in English will be at the C2 level. Subsequently, the study of specialized disciplines in the magistracy will continue mainly in English.

In our opinion, all the planned changes reflected in the State Program should have a beneficial effect on the system of higher and postgraduate education in the republic, increase its prestige in the eyes of potential entrants. But for the implementation of the tasks set it is necessary to attract large-scale resources and spend a great amount of time since there are very few personnel capable of conducting training sessions not in language disciplines in the republic, and those who do exist expect to receive a decent remuneration for their work and are unlikely to want to work in universities.

Therefore, with the tasks set, it will take at least 4-5 years in order to have time to prepare young cadres for teaching in foreign languages, as well as to develop a curriculum that meets the requirements of the State Program for the Development of Education. In addition to the resources mentioned above, it will also be necessary to spend money on the development of the curriculum, the creation of educational and methodological complexes in the selected disciplines, their testing and printing. In our opinion, the State Program sets deadlines that are too tight for the entire volume of work mentioned above, which don't take into account the real state of affairs in the field of education.

Thus, higher professional education has a large-scale impact on civilization, the level of social, socioeconomic, technological development and has a powerful potential for self-organization and self-correction.

It is from these positions that the higher education system should form the potential for its renewal. First of all, this concerns the renewal of the conceptual and methodological foundations of higher professional education, taking into account the best domestic and foreign achievements of the university education system. A systemic comparative analysis of the content components of all levels of the domestic and foreign education systems is required, taking into account its structural integrity, system-forming ties and the hierarchical interdependence of the constituent parts.

The main goal of the development of the system of higher professional education is to satisfy the longterm strategic interests of society, the state and the individual, to improve the quality of training of specialists through systematic and purposeful reform of the university system. Reforms in the higher education system are designed to bring Kazakhstan to the forefront in the world, to ensure the future of the Kazakh nation, a decent life for every citizen.

\section{References}

1 Байденко В.И. Болонские реформы: некоторые уроки Европы / В.И. Байденко // Высшее образование сегодня. 2017. — № 2. - C. 14-19. 
2 Лукичев Г. Болонский процесс: суждено ли измениться образованию в ЕС / Г. Лукичев // Поиск. — № 35. — С. 7.

3 Кунанбаева С.С. Болонская конвенция и международное научно-образовательное пространство / С.С. Кунанбаева // Вестн. Казах. нац. ун-та - 2020. — № 4. - С. 46-48.

4 Байсеитова Ж.Б. Современное состояние системы высшего образования в Республике Казахстан / Ж.Б. Байсеитова // Вестн. Казах. нац. ун-та. — 2019. - № 6. - С. 55-59.

5 Нечаев В. Болонский процесс: мифы, иллюзии, реалии / В. Нечаев // Высшее образование в России. — 2024. - № 7. - C. 86-95.

6 Соснов А. Из Берлина в Берген: Болонский экспресс набирает обороты / А. Соснов // Поиск. — 2016. — № 46. — C. 4.

7 Исаев К. Реформы в системе образования Республики Казахстан: проблемы подготовки специалиста будущего / К. Исаев, А.Акчурин // Высшая школа Казахстана. — 2004. - № 3. - С. 33-38.

8 8. Государственная программа развития образования в Республике Казахстан // Астана. primeminister.kz.Retrieved from https://primeminister.kz/en/news/16716.

\title{
К.Т. Тлеужанова, Ж.С. Купеева, А.Ж. Игембекова, Г.М. Магауина Қазақстанның заманауи білім беру саласындағы
артықшылықтары мен мәселелері
}

\begin{abstract}
Мақалада Қазақстан Республикасында тиімді білім беру бағдарламалары мен стандарттарын қолдану сияқты білім беру үшін маңызды тақырып талқыланған. Сондай-ақ, білім беру саласының қазіргі жағдайы мен оның тиімділігін реттейтін білім саласындағы негізгі бағдарламалық құжаттар талданып, еуропалық білім беруді қазақстандықтармен салыстырған мысалдары келтірілген. Мақалада қазақстандық жоғары білім берудің, оның ішінде нарықта оқу орындарының (университеттермен) шамадан тыс толығуы, білім берудің қымбат құны, техникалық мамандардың жетіспеушілігі сияқты мәселелері ашылған. Білім берудегі кемшіліктер мен оларды жоюдың ықтимал тәсілдерінің бірі 2018 жылы қабылданған Қазақстан Республикасының білім беруді дамытудың 2018-2020 жылдарға арналған Мемлекеттік бағдарламасы туралы идея негізделген. Практикалық тәжірибені қорыта келе, мақалада білім беру жүйесінің өзгеруі мен оны жаңартудың негізгі кезеңдері қарастырылған. Мамандардың құзыреттілігін арттыру аясында біздің елдің жетекші жоғары оқу орындарына түсу емтихандарын жетілдіру қарастырылуда. Өндіріс пен жұмыс күші жетіспейтін аймақтардың кәсіпорындарын кадрлармен толықтыру мақсатында «Мәңгілік Ел жастары - индустриясы» әлеуметтік жобасын іске асыру жалғасуда. Бұл жоғары оку орындарының түлектерін, оның ішінде ауылдық жерлерде еңбек нарығының қажеттіліктерін ескере отырып, жұмыс орындарын ұсынуды білдіреді. Қорытындылай келе, білім беру жүйесін жетілдірудің барлық мүмкін жолдары ашылған, нәтижесінде Мемлекеттік бағдарламада көрсетілген барлық жоспарланған өзгерістер республикадағы жоғары және жоғары оқу орнынан кейінгі білім беру жүйесіне тиімді әсер етуі, яғни әлеуетті талапкерлердің алдында оның беделін арттыру керек.
\end{abstract}

Кілт сөздер: білім беру нарығы, тест нәтижелері, жалпы білім беру ұйымдарының түлектері, мектептер, енбек нарығы, соңғы үш онжылдықта білім беру қызметтері, ақылы негіз, талаптардың жоғарылауы, заманауи тенденциялар, білім беру жүйесі, сапалық реформа, әлемдік стандарттар.

\section{К.Т. Тлеужанова, Ж.С. Купеева, А.Ж. Игембекова, Г.М. Магауина}

\section{Перспективы и проблемы в сфере современного образования Казахстана}

В статье рассмотрена такая важная для образования тема, как применение программ и стандартов эффективного образования в Республике Казахстан. Проанализированы текущее состояние сферы образования и основные программные документы в сфере образования, регламентирующие его эффективность, даны примеры сравнения европейского образования с казахстанским. Авторами раскрыты проблемы казахстанского высшего образования, такие как перенасыщение рынка образовательными учреждениями (вузами), дорогая стоимость образования, нехватка специалистов технического профиля. Обоснована идея об одном из возможных путей устранения недоработок и пробелов в образовании, а именно принятая в 2018 г. Государственная программа развития образования РК на 2018-2020 гг. Обобщая практический опыт, авторы изучили ключевые этапы изменения состояния системы образования и его модернизации. В рамках повышения компетентности специалистов рассмотрено усовершенствование вступительных экзаменов в передовые вузы нашей страны. В целях насыщения кадрами производства и предприятия трудодефицитных регионов продолжается реализация социального проекта «Мәңгілік Ел жастары - индустрияға». Это подразумевает обеспечение местами трудоустройства выпускников вузов, в том числе и в сельской местности, с учетом потребностей рынка труда. В заключение раскрыты всевозможные пути улучшения системы образования, что в результате долж- 
но способствовать тому, что отраженные в Государственной программе планируемые перемены должны благотворно повлиять на систему высшего и послевузовского образования республики, повысить ее престиж в глазах потенциальных абитуриентов.

Ключевые слова: рынок образования, результаты тестирования, выпускники общеобразовательных школ, школы, рынки труда, за последние три десятилетия, образовательные услуги, платная основа, повышенные требования, современные тенденции, система образования, качественная реформа, мировые стандарты.

\section{References}

1 Baidenko, V.I. (2017). Bolonskie reformy: nekotore uroki Yevropy [Bologna reforms: some lessons of Europe]. Vysshee obrazovanie segodnia - Higher Education Today, 2, 14-19 [in Russian].

2 Lukichev, G. Bolonskii protsess: suzhdeno li izmenitsia obrazovaniiu v ES [Bologna Process: Is Education in the EU Fated to Change]. Poisk - Search, 35, 7 [in Russian].

3 Kunanbaeva, S.S. (2020). Bolonskaia konventsiia i mezhdunarodnoe nauchno-obrazovatelnoe prostranstvo [Bologna Convention and International Scientific and Educational Space]. Vestnik Kazakhskogo natsuonalnogo universiteta - Bulletin of $\mathrm{KazNU}, 4,46-48$ [in Russian].

4 Bajseitova, Zh.B. (2019). Sovremennoe sostoianie sistemy vysshego obrazovaniia v Respublike Kazahstan [The current state of the higher education system in the Republic of Kazakhstan]. Vestnik Kazakhskogo natsuonalnogo universiteta - Bulletin of KazNU, 6, 55-59 [in Russian].

5 Nechaev, V. (2004). Bolonskii protsess: mify, illiuzii, realii [Bologna process: myths, illusions, realities]. Vysshee obrazovanie v Rossii - Higher Education Russia, 7, 86-95 [in Russian].

6 Sosnov, A. (2016). Iz Berlina v Bergen: Bolonskii ekspress nabiraet oboroty [From Berlin to Bergen: Bologna Express Gains Traction]. Poisk - Search, 46, 4 [in Russian].

7 Isaev, K. (2004). Reformy v sisteme obrazovaniia Respubliki Kazakhstan: problemy podgotovki spetsialista budushchego [Reforms in the education system of the Republic of Kazakhstan: problems of training a specialist of the future]. Vysshaia shkola Kazakhstana - Higher School of Kazakhstan, 3, 33-38 [in Russian].

8 Gosudarstvennaia programma razvitiia obrazovaniia v Respublike Kazakhstan na 2017-2020 gody [State program for the development of education in the Republic of Kazakhstan for 2017-2020]. (2019). Astana. primeminister.kz.Retrieved from https://primeminister.kz/en/news/16716 [in Russian]. 